\title{
The Idealism and Pantheism of May Sinclair"
}

ABSTRACT: During the early twentieth century, British novelist and philosopher May Sinclair published two book-length defenses of idealism. Although Sinclair is well known to literary scholars, she is little known to the history of philosophy. This paper provides the first substantial scholarship on Sinclair's philosophical views, focusing on her mature idealism. Although Sinclair is working within the larger British idealist tradition, her argument for Absolute idealism is unique, founded on Samuel Alexander's new realist beliefs about the reality of time. Her metaphysics takes idealism and pantheism in new directions and provides fresh insight into I920s debates between British idealisms and realisms.

KEYWORDS: May Sinclair, British idealism, time, Samuel Alexander, pantheism

\section{Introduction}

May Sinclair (I 863-I946) was a British novelist, feminist, and idealist philosopher. Although there is substantial scholarship on her fiction and her feminism, there are no detailed studies of her philosophy. This is unfortunate because Sinclair developed a unique kind of idealism, partially sourced in the work of realist Samuel Alexander. Sinclair takes on Alexander's belief that we must 'take time seriously', and provides a rare idealist attempt to do just that. Her system illuminates the possibilities of idealism and pantheism, and offers a fresh perspective on I920s interactions between British idealisms and realisms. This article addresses the neglect of Sinclair's philosophy by providing the first substantial enquiry into it. I explore Sinclair's mature idealism and pantheism, found principally in her 1922 The New Idealism, and contextualize her work within its period. Sinclair's philosophical views are intertwined with her fiction, and I gesture toward some of the links.

The paper proceeds as follows. Section I introduces Sinclair's life and work and situates it within early twentieth-century British philosophy. I show that she became a 'British idealist' at a time when idealism was slowly dying out in Britain, superseded by 'new realism'. Section 2 excavates what I believe to be Sinclair's core positive

\footnotetext{
* This article is the third in a special series of commissioned articles on women in the history of philosophy. The second article 'Olympe de Gouges versus Rousseau: Happiness, Primitive Societies, and the Theater', by Sandrine Bergès, appeared in Volume 4, Issue 4, pp. 433-45I.

The research for this article was generously supported by the Pantheism and Panentheism Project, funded by the John Templeton Foundation. I am also grateful to James Connelly, Yujin Nagasawa, Jeremy Dunham, Sophia Connell, Keith Ansell-Pearson, Matthew Duncombe, and an anonymous referee for this journal for helpful comments on earlier drafts.
} 
argument for idealism. She argued that idealism can only survive if it takes on elements of realism, and she took on realist concern with the nature of time. However, against realism, Sinclair argues the only way to account for time is to involve consciousness. Sinclair ultimately posits an Absolute consciousness, and identifies this Absolute with the universe. As she also identifies the Absolute with God, her system is a kind of pantheism. Section 3 discusses Sinclair's pantheism in detail, showing that space and time are necessary to creation, and exploring her unique account of omniscience. This study aims to open new paths for scholarship on Sinclair, for historians of philosophy, as well as for scholars of literature and feminism.

\section{Sinclair and Early Twentieth-Century British Philosophy}

Sinclair grew up near Liverpool, in a difficult family. Born Mary Amelia St. Clair, she later changed her name to May. She was largely educated at home, but in I 88 I she was sent for a brief stay at Cheltenham Ladies' College, where the headmistress Dorothea Beale encouraged her to read philosophy. Around this period Sinclair read historical works by Plato, Spinoza, Locke, Johann Gottlieb Fichte, and Kant, as well as contemporary works by British idealists such as T. H. Green and Edward Caird. Although Sinclair's interest in philosophy continued, she did not pursue a professional career in academia.

Sinclair resolved to be a writer, and in I 897 she published her first novel, Audrey Craven. Although it was fairly well received, it was her third novel, The Divine Fire (I904), that brought Sinclair wealth and success. This book became a bestseller in America. Following its success, the writer Ford Madox Ford (I93 I: 326) stated, 'Parties were given at which examinations were held as to the speeches of the characters in Miss Sinclair's book'. Sinclair traveled around America, meeting the likes of Ralph Waldo Emerson and William James, and going motoring with President Theodore Roosevelt; on this and other anecdotes, see Raitt (2000: 95-96). She became friends with H. G. Wells, W. B. Yeats and Thomas Hardy. Sinclair's work especially impressed T. S. Eliot, another writer with a deep interest in British idealism; see Neff (I980). During World War I, Sinclair visited the Belgium front lines with an ambulance corps, and she published an account of it in I9I 5. In I9I6 she was elected a fellow of the Royal Society of Literature. Toward the end of her life Sinclair became ill, and she wrote nothing after 1927. For more on Sinclair's biography, see Boll (I973), Raitt (2000), and Saunders (2007).

Over the course of her career, Sinclair published twenty-one novels, many volumes of short stories and poetry, and works of literary criticism. She defended the Women's Suffrage League in a I9I2 pamphlet, Feminism. Substantial scholarship exists on Sinclair's fiction; major studies include Boll (I973), Raitt (2000), Kunka and Troy (20II), Bowler (20I6), and Bowler and Drewery (20I7). Sinclair's feminism is also well studied: see Boll (I973: 25I-23), Raitt (2000: I04-I3), Forster (2003), Pease (2006), and Gough (2009). Yet Sinclair was also an idealist philosopher.

Her work emerged during a tumultuous period of British philosophy. In the late nineteenth century, British philosophy was dominated by a movement known as 
Absolute idealism. This view, heavily sourced in Kant and Hegel, held that the universe is a single Absolute consciousness. As the Absolute is singular and partless, Absolute idealism provides a kind of 'existence monism': in reality, only one thing exists. Ultimate reality is the Absolute, and all else is appearance. British Absolute idealists included William Wallace, Edward Caird, T. H. Green, Bernard Bosanquet, and F. H. Bradley. Of their works, Bradley's I 893 Appearance and Reality is the best known today.

Around the turn of the twentieth century, challenges emerged to Absolute idealism. One challenge was new forms of idealism. Concerned that Absolute idealism does not allow for the individuality of persons or selves, 'personal idealists' such as Andrew Seth Pringle-Pattison and H. G. Sturt argued that reality is pluralist: it is composed of many minds. For at least Pringle-Pattison (I 887: 216) this plurality ultimately forms a unified Absolute, on which persons are 'parts of the system of things'. On personal idealism, see Cunningham (I933), Passmore (I957), Mander (20II), and Dunham, Grant and Watson (20I I). Other idealists argued for more thoroughgoing forms of pluralisms. Idealist 'monadologists' - including James Ward, J. M. E. McTaggart, and Hilda Oakeleygrounded their systems in Leibniz's Monadology. They held the universe comprises a plurality of unique, independent monads or persons. On Ward and McTaggart, see Mander (20II); on Oakeley, see Thomas (2OI 5 ).

Another challenge to Absolute idealism was the rejection of idealism altogether. The 'new realists' included Bertrand Russell, G. E. Moore, A. N. Whitehead, John Laird, Susan Stebbing, and Samuel Alexander. New realism was characterized by the pluralist view that many things exist and relations hold between them, and by appeals to science and mathematical logic. Groundbreaking realist texts included Moore's I 899 'The Nature of Judgment' and Russell's I903 The Principles of Mathematics.

Realism quickly gained ground and, by the I9 Ios, idealism of all kinds was on the back foot. It did not help that major idealist stalwarts were passing away. Many first-wave idealists, including Green, had passed away by the turn of the twentieth century. Of the second wave, Bosanquet and Bradley passed away in I923 and I924 respectively. Although idealism sputtered in the I920s and I930s, it was not snuffed out. Later idealists continued to publish and debate their ideas, including Harold Joachim, J. H. Muirhead, J. S. Mackenzie, A. E. Taylor, and Oakeley. This was the British philosophical scene that Sinclair engaged with, and her work forms part of this late wave of British idealism. For more on idealism's 'afterlife', see Mander (201 I: 526-56).

Sinclair published philosophy throughout her career. After her stint at Cheltenham Ladies' College, she authored pieces on Plato and Descartes for the Cheltenham Ladies' College Magazine, and later published in philosophy journals. In her fifties, Sinclair authored two books defending idealism: A Defence of Idealism (I9I7) and The New Idealism (I922). Sinclair (I922: ix) describes the earlier book as 'light-hearted' (which does not do the dense and careful monograph justice). She explains that the later book is an attempt 'to remedy the many shortcomings' of its predecessor. Critical editions of both books are forthcoming from the Edinburgh University Press. 
Sinclair's idealism leaks into her fiction, which is why her idealism is of interest to literary scholars. Gillespie (I978, I38) argues that Sinclair sees art and metaphysics as 'inseparable'. Many of Sinclair's characters are philosophers or artists, and they often explore philosophical ideas. For example, her first book Nakiketas and other Poemspublished in I 886 under the pseudonym Julian Sinclair-has Death saying,

Knowledge is Being ...

Man works, and from the clay of his own hands,

Or dreams of his own soul, he shapes the gods. (Sinclair I 886: I2-I3)

As Raitt (2000: 36) observes, 'Sinclair's Death is an idealist'. Sinclair's idealism is also explicit in her short story 'Finding the Absolute', discussed below.

Sinclair's philosophy books were widely reviewed, although their reception was mixed. Reviewers consistently praised her dynamic style. For example, Harvey (I9I9: 554) describes Sinclair's writing as 'sparkling': 'there is no doubt that the manifestation of the absolute in Miss Sinclair has a tremendously good time and dances ecstatically among the struggling philosophies like the fabled Irishman at the fair, looking for heads to hit'. Calkins (I9I9: I27) actually finds the 'vivacity' of Sinclair's writing 'wearisome'.

Although Sinclair's critiques of new realism were occasionally addressed, her positive arguments for idealism often went unremarked, or were dismissed. To illustrate, I look at Russell's two reviews of A Defence of Idealism. On the one hand, Russell (I9I7a: 590) describes it as 'extremely interesting and full of good things'. On the other hand, Russell (I9I7b: 38I) describes Sinclair as an 'amateur' philosopher, a breed of thinker that does not invent new systems but rather interprets existing ones for the general public. The Russell scholar Ray Monk (I996: 505) seems to agree, writing 'it is at first glance difficult to see why Russell took her book and her views so seriously'; he attributes this solely to Russell's respect for Sinclair's amateur status and engaging writing style. Russell began corresponding with Sinclair on philosophy from I9I7 onward and invited her to lunch on the day of his first lecture on mathematical logic. Reportedly she promised 'not to write on philosophy again' until she had considered all the points he raised (see Monk I996: 506). Some of their correspondence survives in the Bertrand Russell archives, McMaster University.

Mary Whiton Calkins, another rare woman philosopher of the period, is more appreciative of Sinclair's philosophy. Calkins (I9I9: I23) writes that any reader who takes up Sinclair's Defence will discover 'no simplified, superficial re-wording of other people's conclusions but rather an independent and critical study of fundamental doctrines'. Laird (I923: II6) wrote of The New Idealism that it keeps up a 'brisk bombardment' of realism 'with the most pertinacious freshness and pith' but is unconvinced by her arguments. Russell (I922: 625-56) continued to stir condescension into his approbation of Sinclair's second philosophy book, implying that its value lies in its writing style rather than its 'actual contribution to the corpus of philosophy'. Russell does, however, allow that The New Idealism is 'one of the best' recent defenses of idealism. Frustratingly, Laird and Russell do not engage with the arguments of The New Idealism in any depth. 
In recognition of her work, Sinclair became a member of the Aristotelian Society in I9I7. She discusses her membership in a letter to Russell. Sinclair (I9I7b) writes that the society would not previously allow her to become a member: 'they said they would not have women in because you can't knock them about'. 'Now,' Sinclair adds, 'I don't mind being knocked about, in fact, I like it'. Despite these remarks, there were earlier women members of the society, such as Beatrice Edgell, so the society's exact attitude to women members is unclear. On joining the society, Sinclair was apparently happy there, serving their Executive Committee between I922 and I926.

Following an Aristotelian Society talk Sinclair gave in I923, J. H. Muirhead invited her to contribute to his collection Contemporary British Philosophy. The volume aimed to provide 'picture' of current British philosophy, featuring thinkers such as Broad, Bosanquet, Laird, McTaggart and Russell. In his invitation, Muirhead notes 'there is no other woman writer on the list'; see Boll (I973: I9). Despite Muirhead's entreaty, Sinclair did not contribute to the volume.

Later, Sinclair's interests in idealism led her to psychology and psychoanalysis. She joined the Society for Psychical Research, which aimed to prove human survival after death through experimental means. She also became a founding member of Dr. Jessie Margaret Murray's Medico-Psychological clinic. On Sinclair's psychological work, see Boll (I973: 256-60) and Raitt (2000: 109-44).

In one of the few philosophy encyclopedia entries on Sinclair, Mander (2005: 956) observes that her views 'never became widely known' and 'provoked little response'. This is at least partly because of their timing. Sinclair was advocating an idealist metaphysics at a time when idealism was slowly fading away. She was well aware of this:

There is a certain embarrassment in coming forward with an Apology for Idealistic Monism at the present moment. You cannot be quite sure whether you are putting in an appearance too late or much too early. It does look like personal misfortune or perversity that, when there are lots of other philosophies to choose from, you should happen to hit on the one that has just had a tremendous innings and is now in process of being bowled out. (Sinclair I9 I7a: vii)

Sinclair's philosophical work has also been neglected in the history of philosophy. She is not mentioned in many studies covering British idealism, such as Cunningham (I933); Passmore (I957); Dunham, Grant, and Watson (20II); or Boucher and Vincent (2OI2). Nor is she mentioned in studies of historical women philosophers, such as Kersey (I989) or Warnock (I996). Her philosophical views are occasionally touched on by literary scholars, including Boll (1973), Gillespie (I978), Raitt (2000), and Bowler (2016). And by historians of philosophySinclair's idealism is briefly described in Mander's British Idealism (20II: 53I-32), and more substantially in Waithe's History of Woman Philosophers (I995: 3 I 5-20)-although there are no detailed studies of Sinclair's philosophical system. 


\section{Sinclair's Core Argument for Idealism}

Sinclair is an Absolute idealist. 'The world', Sinclair (I922-23: I I I) writes, 'arises in consciousness, through consciousness, and is of that stuff, with no independent existence apart from it'. The New Idealism advances many arguments in favor of idealism, including negative arguments comprising critiques of realism. Below I give a few brief examples of these negative arguments.

The material, pluralist world posited by realism is arguably closer to our everyday perceptions than the minded, monistic world of Absolute idealism. This seems to lend realism the following philosophic advantages: it is commonsensical, it need not distinguish between appearance and reality, and it does not require knotty metaphysics. As Sinclair (I922: 49) puts it, realism looks as if it is true. The great thing about her critiques is that they remove that veneer of truth-seeming. In fact, new realist systems are not commonsensical, they do distinguish between appearance and reality, and their metaphysics is knotty. To illustrate, Sinclair (I922: 20) objects to Russell's view that all we perceive are sense data, and sense data are all that exists. Sinclair argues this view entails 'we are perceiving different universes and there will be as many universes of sensible qualities as there are spectators'. Sinclair (I922: 47-48) lambasts Laird's realist theory of memory, on which remembering literally involves perceiving the past. What, she asks, can this theory say to the phenomenon of remembering a mountain and then imagining tearing it down? She argues a theory of memory on which we are not literally perceiving the mountain is preferable. Sinclair (I922: I98) also dissects Alexander's account of mind-body emergence, pressing him on how, exactly, a new quality of mind can emerge from the existing quality of body. These worries are as sound today as they were a century ago.

All Sinclair's arguments for idealism, positive and negative, deserve attention. However, for lack of space, this paper will focus on what I take to be her 'core' positive argument for idealism. Sinclair foreshadows the argument in the opening pages of The New Idealism:

Realism is ten times more formidable than it was in I9I7.

And since I9I7 the issue has been narrowed down to the field of Space and Time, and it is there that the battle between realism and idealism must be fought. (Sinclair I922: vii)

Realism and idealism will fight on the battleground of space and time. Later, she explains:

What is required of metaphysics is . . the solution of precisely such problems as the antimonies of Space and Time. I think you will not solve the contradictions of Space and Time . . . by leaving out ultimate mind. At any rate the experiment has been tried, and I think it has failed.

It is idealism's turn now. (Sinclair I922: 222) 
Sinclair argues that where realism has failed to explain the nature of space and time, idealism can. She assumes that realism and idealism are the only metaphysical theories on the table so, if she is correct, we have a strong reason to adopt idealism.

The core argument occurs toward the middle of The New Idealism, in a chapter titled 'Space, Time and Consciousness'. As I reconstruct it, the argument has five premises and a conclusion. Although Sinclair discusses time and space, the bulk of the argument concerns time, so that is my focus:

I. We should prefer a metaphysics that can account for our perception of time

2. If taken by itself, time would be discontinuous

3. Yet we perceive time as continuous

4. Realism cannot account for our perception of time as continuous

5. Idealism can account for our perception of time as continuous

6. We should prefer an idealist metaphysics

I discuss each step of the argument in turn.

The first premise ( $\mathrm{I}$ ) is uncontroversial. Many metaphysical theories, including realism and idealism, seek to provide an account of reality that accounts for our perceptual experience. As time is a fundamental part of our perceptual experience, it is reasonable to prefer a metaphysics that can account for it.

The second premise (2) is a kind of thought experiment. Sinclair asks: If we could take time by itself, what would time be like? Her answer is that time would be discontinuous. She describes this in the following way:

Time taken by itself, is utterly attenuated; so far from covering Space, it falls like a thin thread of rain, drop by drop, across that immensity and for ever...

Time can never hope to recover its own past or to grasp its own future. It knows nothing but the present, and the present is a vanishing point between a not-yet-existing future and a no-longer-existing past.

In the same way the body in motion lets go the past point-instant and has no grip of the future as such. It is at a point at an instant; at another point at another instant, as far as the elements of time, space and matter are concerned that is all that can be said about its motion. The change of point-instants which is the essence of the affair remains a miracle. (Sinclair I922: 224-25)

This passage is difficult to understand. I read it as follows: I interpret Sinclair as describing a universe in which the present moment exists, and past and future moments do not. Today, this theory is known as 'presentism'. In contrast, 'eternalism' holds that the past, present and future exist. These labels appear in the I980s, so obviously early twentieth-century philosophers do not use them. Nonetheless, Sinclair is describing a presentist universe: she claims the present 
is a 'vanishing point' between a 'not-yet-existing future' and a 'no-longer-existing past'.

I believe that Sinclair found a special problem of continuity for proponents of a presentist universe. This problem is pointed at in the final lines of the passage above, and concerns motion. To understand it, consider one of Zeno's paradoxes of motion, the 'arrow paradox'. Above, we saw Sinclair claim that metaphysics should solve the 'antimonies' of space and time; this is one of the problems she has in mind.

Zeno's arrow paradox is recorded in Aristotle:

[Zeno] says that if everything when it occupies an equal space is at rest, and if that which is in locomotion is always in a now, the flying arrow is therefore motionless ... to the effect that the flying arrow is at rest, which result follows from the assumption that time is composed of moments. (Aristotle Physics, 239b5-32)

A flying arrow seems to be motion. Yet Zeno argues that at any moment of the arrow's flight, the arrow is 'at rest'. Zeno assumes that time is composed of a plurality of moments, each of which depicts whatever is happening in space at that instant. In figure $I$, one moment is $t_{I}$ and the next is $t_{2}$, and so on. At each of these moments, the arrow hangs motionless at a different point in its flight, like stills in a vintage film. As the arrow's flight is purely composed of such moments, Zeno concludes that at no point is the arrow in motion. Sinclair (I922: I39-40) puts it thus: 'The arrow cannot fly, because going from next point-instant to next, it is stationary at each point at each instant'. The arrow paradox has grand consequences: if a flying arrow is not in motion, then nothing, anywhere in the universe, is in motion. Despite appearances, motion is impossible.

Huggett (2017) provides a comprehensive overview of Zeno's paradoxes, and a solution to this one. Huggett writes the only answer to the arrow paradox is that the arrow moves from one place to another over time simply by occupying different points at different times: 'the arrow never changes its position during an

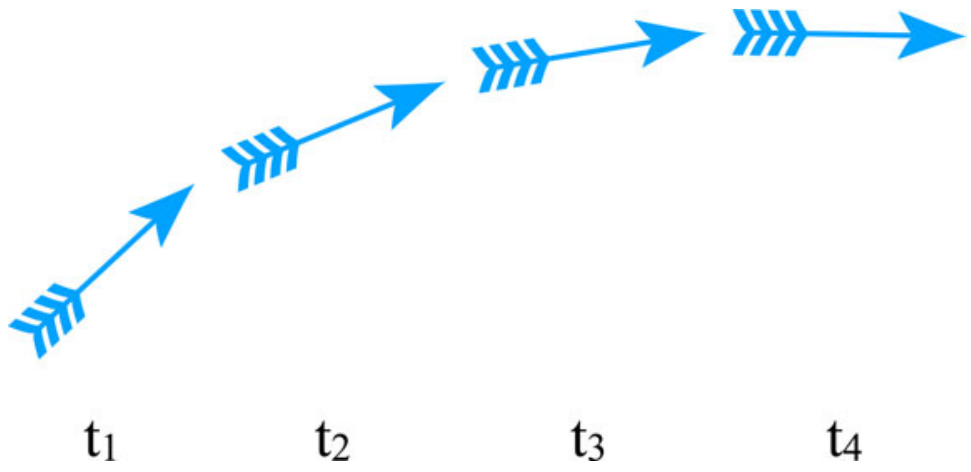

Figure I. Arrow's flight over time. 
instant but only over intervals composed of instants'. The key point is that the arrow only changes its position over intervals composed of instants. In other words, change is only possible during multiple moments of time, not over a single moment. In figure $I$, there is no motion at $t_{I}$. Nor is there motion at $t_{2}$. There is only motion across $t_{I}$ and $\mathrm{t}_{2}$.

You might think this poses a special problem for a presentist universe. On an eternalist universe, all moments of time exist simpliciter, so a multiplicity of moments co-exist through which the arrow flies. In contrast, on a presentist universe, only one moment of time exists simpliciter. This means there is no multiplicity of coexisting moments through which an arrow flies. I read Sinclair as articulating this problem. She believes time by itself would be discontinuous, in the sense there is no multiplicity of moments through which things move. This is why she describes the motion of a body over time as a 'miracle'.

Are there any sources for this view in Sinclair? As far as I am aware, these specific worries about continuity or presentism are not found in any other British idealists. Idealists such as Bradley and McTaggart famously reject the reality of time, yet there is no suggestion that Sinclair follows suit. Instead, she seems to be drawing on a new realist text about time: Alexander's 1920 Space, Time, and Deity. The opening pages of The New Idealism state:

I could have done nothing without Professor Alexander's work on Space-Time. Much as idealism owes to idealists, its larger debt must be to the first realist who taught them to 'take Space and Time seriously'. So, after years of devotion to Mr. Bradley's Absolute, I wanted to see what would happen if I simply followed the trail which, thanks to Professor Alexander, I saw before me. (Sinclair I922: x-xi)

Alexander (I920, vol. I:45) also argues that, if time were taken by itself, the moments of time would be discontinuous. Alexander claims that in this case 'there could be no continuity' in time, there would merely be a 'now' which was perpetually renewed. Time would 'consist of perishing instants'; for more on this, see Thomas (2013: 556-57). Alexander is also describing a presentist universe. However, unlike Sinclair, Alexander makes no reference to Zeno's arrow in describing this problem, so we cannot be certain he has precisely the same problem in mind.

Sinclair believes that, if taken by itself, time would be discontinuous. Implicitly, she assumes that if we perceived time by itself, we would perceive that discontinuity. It is difficult to know what that would be like. Perhaps when we perceived an arrow in flight it would jerk or jump from one moment to the next. Of course, Sinclair does not believe we perceive time as discontinuous. Instead, she argues for the third premise (3): we perceive time as continuous. Sinclair points to bodies in motion:

bodies do move through unmoving space in moving time; they do stand still in a moving time and unmoving space; and their movement is apparently continuous. (Sinclair I922: 225) 
Imagine watching an arrow fly past a tree. The arrow moves from one part of space to another, over time. The tree does not move through space, yet it moves through time. The motion of the arrow and the tree through time seems to be continuous. Alexander ( 1920 , vol. I:39) also argues that time is experienced as 'continuous', 'a duration of the successive', its distinguishable parts 'not isolated but connected'.

Sinclair may also have the psychology of her period in mind here. In her earlier work, Sinclair (I9I7a: 294) refers to William James's I890 view that consciousness is given 'in a continuous unity'. James (I910: 237) argues, 'Within each personal consciousness, thought is sensibly continuous'. He goes on to define 'continuous' as 'that which is without breach, crack, or division' (237). Perhaps if we could perceive discontinuous time, the experience would be the polar opposite of this: a consciousness exhibiting breaches, cracks or divisions. It's worth noting that Sinclair was the first to use James' stream of consciousness metaphor to describe a work of literature; see Gillespie (I978).

So far, the argument has run as follows. Premise 2 claims that time by itself would be discontinuous. Premise 3 claims that we perceive time as continuous. On Sinclair's view, the only way to explain our perception of time as continuous is that we do not perceive time by itself. There must be something in addition to time, which leads us to perceive time as continuous. What might that extra ingredient be? An answer is found in the work of Alexander, who argues that the extra ingredient is space. Sinclair believes Alexander's answer is the strongest of all realist answers, so if she can show it fails, she will have shown (premise 4): realism cannot account for our perception of time as continuous. To explain Alexander's account, and Sinclair's attack on it, we must go deeper into the metaphysics.

Alexander's Space, Time, and Deity claims that space and time are the emergence base of all things. Alexander (I920, vol. 2:45) argues when 'motions' or patterns within space and time become complex enough, new qualities emerge. In this fashion, matter emerges from space and time, followed by life, mind, and finally deity. Space and time are the foundation of Alexander's metaphysics, and he describes how they would be if taken by themselves. As I discuss above, he believes that, if we took time by itself, its moments would lack continuity. Alexander (I920, vol. I:47) further claims that space taken by itself would be a mere 'blank', 'a whole of co-existence' with 'no distinction of parts'.

Although Alexander claims that time by itself would be discontinuous, he believes we perceive time to be continuous. Similarly, although he claims that space by itself would lack parts, Alexander (I920, vol. I:39) believes we perceive space to 'contain distinguishable parts'. Why don't his descriptions of time and space taken independently match our perceptual experience? Because, in reality, time and space are unified. On Alexander's metaphysics, time and space provide each other with the features they individually lack:

Space and Time depend each upon the other, but for different reasons... Without Space there would be no connection in Time. Without Time there would be no points to connect . . . each of the two, Space and Time, is vital to the existence of other. (Alexander I920, vol. I:47-48) 
He believes that space provides time with continuity, allowing the parts of time to connect and become a continuous successive duration. Space is continuously extended in length, breadth, and depth, and space can lend its continuous extension to time. Just as space continuously connects different spatial places, so space can continuously connect different moments of time. Meanwhile, time breaks up space into parts.

Despite how impressed Sinclair is by Alexander's system, she attacks it on several grounds, including its unification of space and time. She argues that space does not provide time with continuity:

For all its spaciousness Space cannot hold down more instants than one at a time. The past has gone from it, its grip on the future has not yet begun. (Sinclair I922: I68)

To understand this objection, remember that above I read Alexander as arguing that time by itself would lead to presentism. Yet Alexander is an eternalist. Alexander ( 1920 , vol. I:44) claims that 'Physical Time' is a succession from earlier to later. We can speak of past, present, and future in physical time, as long as we appreciate that the present is a moment of physical time 'fixed by relation to an observing mind'. In physical time there is no presentness, points are merely earlier or later than one another. Alexander (I920, vol. I: 63) compares his eternalist universe to a closed vessel containing gas, in which the gas molecules dash about 'in all manner of lines of advance'. We can choose any gas molecule to act as the 'centre of reference', to be the present moment. Its fellow molecules stand at various degrees of remoteness from this molecule, representing how near or far away they are in time, yet all are equally real. Thus, he seems to believe that time by itself leads to presentism, yet space and time together leads to eternalism. On Alexander's eternalism more widely, see Thomas (2017: $\mathbb{3}$ ).

I read Sinclair as objecting that uniting space with time does not lead from presentism to eternalism. She is arguing that the 'spaciousness' or extension of space only covers the three dimensions of length, breadth and depth. Space cannot cover perishing 'nows', connecting past or future nows across the fourth dimension of time. On Alexander's account of space-time, space needs to provide continuity across time, and that is exactly what space cannot do.

Sinclair (I922: I68) also argues we should not accept Alexander's claim that space taken by itself lacks parts. As we saw above, Alexander describes space taken by itself as 'a whole of co-existence'. She argues coexistence is a juxtaposition of coexisting points or parts, 'and I cannot see how its points are to be conjured away from Space in the mere absence of Time'. As Sinclair (I922: I77) puts it a little later, space is 'pure juxtaposition': its points are already discriminated by their positions because they are positions.

In Sinclair's view, the best realist account of why our perception of time is continuous has failed. This brings me to premise 5. If there is something in addition to time that leads us to perceive time as continuous, and that 'something' is not space, what is it? Sinclair argues it is consciousness. Through consciousness, the idealist can account for our perception of time as continuous. 
Sinclair introduces her idealist solution with panache:

in our perceptual experience ... [bodies'] movement is apparently continuous ...

And the fact that this does actually happen in our perceptual experience should give us pause. Is it a naif idealism that wonders whether, after all, perception may not have something to do with it? Not more naif, I think, than the realism which assumes that you can subtract perception and everything will go on as before, or add it and it will make no difference.

Only in unminded Space-Time, powerless to retain its own past and future, is there incurable disintegration. Introduce consciousness that joins instant to instant and holds past, present and future together in one duration ... that links point with instant and point-instant with point-instant in one Space-Time; see Space-Time once for all as existing, not in and by and for itself, but as the simplest and most universal form of consciousness, so that all events happening in Space-Time are, ipso facto happening in consciousness, and contradiction disappears. Consciousness secures to events their range in Space, their hold on Time, their past, their present and their future, in a word, their continuity. (Sinclair I922: 225-26)

Only consciousness can explain the continuity we perceive in time because only a consciousness can hold past and future together with the present in one moment. A conscious mind can remember the past and anticipate the future, overcoming the fact the present is a vanishing point between an unreal past and unreal future.

Consciousness can solve the puzzle Sinclair finds in Zeno's arrow paradox, by providing the multiplicity of moments necessary for motion:

In minded Space-Time motion becomes once more thinkable; bodies can and do move ... [Zeno's] arrow will fly. (Sinclair I922: 226)

Through memory, a mind can hold the past points of an arrow's flight together with its present point, to perceive its motion.

To help explain the process whereby consciousness can hold past, present, and future together in one duration, I look to Henri Bergson's r 889 Essai sur les données immédiates de la conscience, translated into English as Time and Free Will: An Essay on the Immediate Data of Consciousness. Bergson distinguishes two conceptions of time. 'Mathematical time' is spatialized, divisible into discrete, countable units. In contrast, 'pure duration' is utterly nonspatial. As Bergson (I9I 2: IOO) writes, it is experienced by conscious beings, when our ego 'lets itself live'. Pure duration does not divide up our moments of temporal experience, instead it:

forms both the past and the present states into an organic whole, as happens when we recall the notes of a tune, melting, so to speak, into 
one another. Might it not be said that, even if these notes succeed one another, yet we perceive them in one another. (Bergson I9I 2: IOO-I)

Sinclair was closely familiar with Time and Free Will (indeed, the fourth chapter of A Defence of Idealism is largely devoted to it, and translates large chunks from the original French). Although she does not reference Bergson in connection with our perception of continuous time, I believe this is the kind of process Sinclair has in mind. Consciousness can pull together the disconnected moments of time, forming past and present states into an organic whole.

To summarize, the premises run as follows: (I) claims that we should prefer a metaphysics that can account for our perception of time as continuous; (2) claims that time taken by itself would be discontinuous; yet (3) claims that we perceive time as continuous; (4) claims that realism cannot account for our perception of time; and (5) claims that idealism can. If the premises of Sinclair's core argument go through, then so does her conclusion (6): we should prefer an idealist metaphysics.

\section{Sinclair's Pantheism}

\section{I. Sinclair's Absolute Idealism and Presentism}

Sinclair is an Absolute idealist, and believes an Absolute consciousness underlies the world around us. Sinclair (I922: 296) identifies the Absolute with God, writing that she does not see how this 'flight to God' can be avoided.

Sinclair's core argument could be read as arguing merely for the importance of human consciousness to explain our perception of time. You could then read her as going on to argue for the Absolute on independent grounds. For example, The New Idealism argues that Absolute idealism is better equipped to answer realist objections than idealisms that do not posit an Absolute (such as idealist monadologies). One objection is how an idealist system grounded on human consciousness can account for anything that existed before humans arrive. If one does not posit an Absolute, Sinclair (I922: 3I3) wryly observes, then dinosaurs 'would be the sustainers of the universe of their time'. However, as I read Sinclair, an Absolute consciousness follows from her core argument. My reasoning is as follows.

I return to Zeno's paradox. Sinclair has solved the problem of the arrow: if $t_{2}$ is the present moment of the arrow's flight, human consciousness can involve its past $t_{I_{I}}$ and its future $t_{3}$ in that present, explaining why the arrow's motion is perceived as continuous.

But Sinclair aims to go beyond arrows. I interpret her as positing continuous motions beyond what humans perceive. Each human consciousness is finite. Few humans have perceived much beyond the planet Earth, and no human perceived anything before we came into existence two million years ago. Yet Sinclair believes comets fly in distant galaxies, and dinosaurs walked the prehistoric Earth. As I read her, she reasons that there are continuous motions throughout the entire universe, so there must be a universe-wide consciousness perceiving those motions. This universe-wide consciousness is the Absolute. This reading is supported by remarks already given above: 
see Space-Time . . . as the simplest and most universal form of consciousness, so that all events happening in Space-Time are, ipso facto happening in consciousness, and contradiction disappears. Consciousness secures to events . . . their continuity. (Sinclair I922: 225-26)

And by remarks such as this:

The plesiosaurus will have disported himself on his mesozoic beach in God's sight, though God had not the happy idea of evolving human minds to enjoy the spectacle of him. Before life was, the earth will have whirled, burned, cooled, upheaved and subsided in the Space-Time of God's consciousness. (Sinclair I922: 30I)

I read Sinclair as making an argument from an analogy, moving from a finite human consciousness to an infinite Absolute consciousness.

A human consciousness is capable of considering a few past and future moments in any present moment. Yet an omniscient Absolute consciousness can consider every past and future moment in any future moment. Sinclair (I922: 246) describes a form of 'ultimate consciousness', on which 'memory and anticipation are complete here and now, all space being known at an instant and all time at a point'. A human consciousness perceives the motion of an arrow to be continuous, and analogously the Absolute consciousness perceives all the motions of the universe to be continuous.

An interesting question for Sinclair is whether her completed system retains presentism. As discussed above, Alexander seems to believe that time taken by itself would produce a presentist universe, yet time taken with space leads to an eternalist one. Does Sinclair similarly believe that time taken with an Absolute mind, a mind that perceives all motions, results in an eternalist universe? She does not say explicitly, but I argue that her ultimate system is at least compatible with presentism.

Above, I quote Sinclair as saying that a human consciousness can hold 'past, present and future together in one duration' (my emphasis). Say $\mathrm{t}_{2}$ is the present moment. Through memory, a human mind can involve a past moment $t_{\mathrm{I}}$ in the present. Through anticipation, a mind can also involve a future moment $t_{3}$ in the present. Analogously, the Absolute consciousness can hold all past moments in the present through memory, and all future moments in the present through anticipation. Sinclair hints at how this process could work in her short story 'Finding the Absolute'. This was first published in Sinclair's 1923 Uncanny Stories, suggesting it may have been written around the same time as The New Idealism. Boll (I973: 303) and Glover (200I) provide short discussions of this story from a literary perspective; as far as I am aware, this is the only scholarship on it.

Although I am wary of reading too much into Sinclair's fiction, 'Finding the Absolute' seems relevant. It runs as follows. An Absolute pantheist named Mr. Spalding dies and finds himself in heaven. While there, Mr. Spalding meets Kant, his philosophical hero, and the pair talk metaphysics in Kant's study. Kant 
explains he has not solved all the riddles of the universe, remarking 'The universe is a tremendous jigsaw puzzle. If God wanted to keep us amused to all eternity, he couldn't have hit on anything better' (Sinclair 2006: I74). However, Kant goes on to explain there is a kind of time which is not linear succession. It is a kind of time 'which has turned on itself twice to take up the past and future into its present' (I74). To show Mr. Spalding how this works, Kant instructs him to look out the window at a cart moving along the street:

What Mr Spalding saw was the sudden stoppage of the cart, which now appeared as standing simultaneously at each station ...

In the same duration of time, which was his present, he saw the townspeople moving in their houses, eating, smoking . . .

The scene stretched and stretched, and still Mr Spalding kept before him each item as it had first appeared. He was now aware of the vast periods of geologic time. On the past side he saw the mammoth and the caveman; on the future he saw the Atlantic flooding the North Sea and submerging the flats of Lincolnshire ...

His stretch widened. He was present at the beginning and the end. $\mathrm{He}$ saw the earth flung off, like an incandescent ball, from the wheeling sun. He saw it hang like a dead white moon in a sky strewn with the corpses of dead worlds ... The whole universe stood up on end round him, doubling all its future back upon all its past ...

And now the universe dissolved into the ultimate constituents of matter, electrons of electrons of electrons, an unseen web, intensely vibrating, stretched through all space and all time. He saw it sucked back into the space of space, the time of time, into the thought of God. (Sinclair 2006: $174-75$ )

Mr. Spalding folds the past and the future into 'the same duration of time, which was his present'. His knowledge of the past and the future has expanded to approach God's, yet these memories and anticipations seem to be crammed into the present duration. This mental act, of involving past memories and future anticipations in the present moment, is compatible with presentism or eternalism.

Some evidence that Sinclair retains presentism can be found in one of her critiques of Alexander's system:

Take the total of Space-Time, Space-Time that was and is and is to be, and you will indeed have all Space covering all Time, and all Time covering all Space; but, if this mutual covering is to be conceived as a complete fit, Time must lose its time character of succession, it will be what Space is, an eternal 'now'. (Sinclair I922: 174) 
As I interpret Sinclair, she is objecting to the plausibility of Alexander's four-dimensional, eternalist universe. She claims that if the past, present, and future exist, time would lose its character of 'succession'. By time's character of succession, Sinclair seems to mean the way things appear to come in and out of existence in time. In this sense, one note of a tune is replaced or succeeded by the next note. On Alexander's eternalist universe, all the notes of the tune exist simpliciter, spread out across real moments of time. The universe is a fixed block. I believe this is what Sinclair means by her description of Alexander's universe as an eternal 'now', an eternal unchanging present. She is objecting that true succession requires things to come in and out of existence simpliciter. This is what happens on a presentist universe: one note of a tune exists at one time simpliciter. Things really come in and out of existence, and time retains its character of succession. If Sinclair believes time should retain succession in this sense, then presumably her universe is presentist.

\subsection{Pantheism and Creation}

Sinclair (I922: 299) believes there is an Absolute consciousness, identified with God, and that reality is this Absolute. Her God has two aspects. There is an immanent aspect, which is our universe. There is also a transcendent aspect, which is beyond our universe. Sinclair (1922: 309) writes that the immanent aspect of God is God's transcendent aspect made 'manifest in Time'. This makes her a panentheist: the universe is 'in' God yet God is not exhausted by the universe. She hints that God manifests himself in this way because of his creative energy. For example, Sinclair (1922: 272-73) writes that the consciousness of God is not 'merely contemplative', it is also 'creative and includes his Will, and the universe is the content and outcome of that creative consciousness'. As Sinclair makes clear here, to speak of 'creation' in this context is not to speak of God as creating things that are separate from him. Rather, we are speaking of creation in the sense that I create my thoughts.

She goes on to argue that space and time are forms of God's thought:

Spirit is the unity of Mind and Will. Space, as pure co-existence, expresses its Mind; Time, as consciousness, its Will. Therefore Mind and Will are as indivisible as their manifestation in Space-Time, and like Space-Time, they are infinite in their being. The divided things, the divided selves, are finite, and this is their appearance, their existence. Their reality, their being, is the infinite and ultimate Self, which is God. (Sinclair I922: 299)

As I read this passage, Sinclair's characterization of space as 'pure co-existence' here refers to her earlier characterization of space as a coexistence of parts. If space expresses a mind, then the mind must be a complex of many co-existing thoughts. Meanwhile, time is the will of God. Sinclair (I922: 30I) adds, 'The universe moves and pulses and has its being in the energy which are forms of God's Will'. If the universe is continually changing over time, perhaps time is God's will in the sense that these changed are willed by God. 
So, the universe is the mind of God, and space and time are God's forms of thought. Why accord space and time this prominence? I argue the answer lies in Sinclair's account of creation. Above, we saw that on Alexander's metaphysics, all existents are generated out of space and time. As it stands, Sinclair argues Alexander's space-time metaphysics fails:

Space-Time, empty of everything but point-instants, can generate nothing but more and more empty Space-Time; not even that without some creative energy behind it. (Sinclair I922: 298)

However, I believe Sinclair accepts space and time could be the crucible of all things, if there were some creative energy behind it. If space and time are the forms of thought of an Absolute being, then they can generate all things:

If I may adopt Professor Alexander's splendid phrases: The universe is begotten by Spirit out of Space-Time. Spirit spreads out the universe in its form of Space. In its form of Time it sweeps all things forward to change and generation. (Sinclair I922: 299)

A similar picture of creation is uncovered by Mr. Spalding in 'The Finding of the Absolute':

When he came out of his ecstasy he was aware that God was spinning his thought again, stretching the web of matter through space and time.

He was going to make another jigsaw puzzle of a universe. (Sinclair 2006: I76)

Alexander and Sinclair agree that space and time are the foundation of our universe. They disagree over whether space and time are the bottommost layer. For Alexander, they are. For Sinclair, they are not: the Absolute lies one layer deeper still.

\subsection{Sinclair's Account of Omniscience}

Sinclair spends some time considering problems for pantheism, and one of her responses to those problems is so original as to deserve special discussion. Sinclair argues pantheism runs into two problems as soon as it tries to explain how God's consciousness is correlated with ours. I discuss them in turn.

Sinclair's (I922: 299-303) 'knowledge problem' asks how much God knows of us. For example, Sinclair argues it is undesirable to say that my consciousness is God's consciousness. If this were the case, all our errors, obscenities and stupidities would flourish in God's mind. Or, if God's consciousness was distinct from ours yet he was still minutely aware of our minds, God would be 'burdened with all our futilities and sillinesses and boredoms ... the listener to millions and millions of idiotic conversations' (302). Theists discuss various problems for God's omniscience, including knowledge of the future, yet I am not aware that anyone has 
discussed this problem in particular. Sinclair's worry that God's consciousness should not be identified with human errors, obscenities and stupidities is arguably related to arguments against omniscience from concept possession. As Nagasawa (2008: 37) explains, the worry is that God's other attributes preclude him from fully understanding certain concepts, such as pain, fear, frustration and despair. Sinclair could be read as arguing that God cannot know error or boredom.

Sinclair's 'moral problem' (I 922: 303-4) asks how God can be identified with all the 'foolishness and badness' of the universe. This is the pantheist version of the problem of evil. The traditional problem argues that the existence of an omnipotent, omniscient and omnibenevolent God is inconsistent with a world containing evil. The pantheist version argues it is inconsistent to identify God with a world containing evil.

Sinclair aims to tackle both problems in an extremely unusual way: by modifying God's omniscience. Traditionally, theists maintain God is all knowing. (Even theists who believe that God lacks knowledge of the future do not hold there are facts God does not know; instead, they usually deny there are facts about the future.) This is the source of the knowledge problem, as an omniscient God should know everything about each human consciousness. In response, Sinclair argues we should give up God's omniscience:

There was a hideous absurdity in the idea that God is vividly aware of our criminal lunacies and idiocies. But suppose he is not vividly aware? Suppose these things exist on a level which is far below the height of God's transcendent consciousness, and that in this sense they are comparatively unreal? Suppose the universe to be literally the body of God, and that it contains our bodies as its parts, much as our bodies contain their cells and the life of the cells. Suppose God's mind to contain our consciousness much as our minds contain the memories and instincts of the cells. Suppose the life of persons lowest in this scale of values to correspond in God's consciousness with this organic cell life which we are hardly conscious of ...

On the other hand our spiritual states will be literally part of God's living consciousness ... He is joined with us consciously every time that we know reality, or create beauty, or will the good. (Sinclair I922: 309)

On Sinclair's system, the morally 'lowest' lives are farthest from God's consciousness, as remote to God as my blood cells are to me. Meanwhile, our 'highest' lives or states are within God's consciousness, such that God shares in our creation of beauty or willed good. If our criminal lunacies are God's blood cells, then our artworks and kindnesses are ideas in God's mind. Once again, Sinclair is drawing an analogy between humans and God, this time to curb God's knowledge.

Modifying God's omniscience in this way also provides her with a response to the pantheist problem of evil. Sinclair (I922: 306-8) argues that God's consciousness is the deepest level of reality. As God is unconscious of human foolishness and badness, that means there is no human foolishness and badness on the bottommost level. Those elements of the human experience are appearance, rather than reality. Sinclair's 
denial of evil on the bottom level of reality belongs to a long tradition of denying the existence of evil, dating at least to Augustine's characterization of evil as a privation.

Sinclair's modification of God's omniscience is extremely unusual. Some theists are willing to modify God's omnipotence or omnibenevolence in response to the problem of evil-see Nagasawa $\left(20 \mathrm{I}_{3}, \mathbb{S} 4\right)$ for an overview-but I am not aware of any willing to modify his omniscience in response. It might be thought especially unusual from a pantheist perspective. Mander (2000: 200) argues it is an advantage of pantheism that divine error is impossible if God's knowledge literally is the world. This identity thesis closes any possible gap between God's knowledge and how things are in the world. In contrast, it is precisely this gap that Sinclair aims to crack open.

Finally, it is worth noting that Sinclair's account of divine omniscience does not merely answer the problems she identifies for pantheism, it also underlies her account of the afterlife. Our spiritual states are part of God's living consciousness, she writes, and this provides us with a form of immortality: 'our spiritual memories will endure in God's consciousness; all that is immortal in us will be remembered there. God will literally be our keeper' (Sinclair I922: 309).

The idea that God will keep memories of us confirms my reading of Sinclair above as a presentist. The implication is that there will come a time where we do not exist simpliciter, yet God will retain memories of us.

\section{Conclusion}

The culmination of Sinclair's idealism is a pantheist Absolute. Yet, to my mind, the heart of The New Idealism lies in what I have labeled its 'core argument': its metaphysics of time. Sinclair sees the gravity of new realism's opposition to idealism, and takes on their concern with time. She comes to believe that although realists are right to worry about time, they cannot explain our experience of time as well as the idealist. If I am right that this is the heart of the book, then-as James Connelly has insightfully pointed out to me-it helps to explain what is and is not present inside its pages. Sinclair does not discuss idealists such as Bradley and McTaggart at length, because she believes they fail to take time seriously. In contrast, she discusses realists such as Alexander and Whitehead at length, because she believes they do take time seriously. After publication, Sinclair sent Alexander a copy of The New Idealism, along with a letter that appears to be part of a longer correspondence. Most of this correspondence is not extant, but another letter, dated March I6, I926, survives. Reflecting on her steadfast idealism, Sinclair adds, 'I'm incorrigible!'

Sinclair's idealism is new, not sourced in idealisms of old but built on fresh realist foundations. As an idealist, Sinclair's decision to take time seriously is extremely unusual, and invites comparison with Oakeley, another rare woman idealist who defended realism about time (see Thomas 2015). Sinclair's twentieth-century idealism is both novel and creative. 


\section{References}

Alexander, Samuel. (I920) Space, Time, and Deity. 2 vols. London: Macmillan.

Aristotle (1984). Physics. In J. Barnes (ed.), The Complete Works of Aristotle: The Revised Oxford Translation, vol. I. (Princeton, NJ: Princeton University Press), 3 I 5-446.

Bergson, Henri. (r912) Time and Free Will: An Essay on the Immediate Data of Consciousness. Translated by F. L. Pogson. London: George Allen.

Boll, Theophilus E. M. (1973) Miss May Sinclair: Novelist. A Biographical and Critical Introduction. Rutherford, NJ: Fairleigh Dickinson University Press.

Boucher, David, and Andrew Vincent. (2OI2) British Idealism: A Guide for the Perplexed. London: Continuum.

Bowler, Rebecca. (2016) Literary Impressionism: Vision and Memory in Dorothy Richardson, Ford Madox Ford, H. D. and May Sinclair. London: Bloomsbury Academic.

Bowler, Rebecca, and Claire Drewery, eds. (2017) May Sinclair: Re-Thinking Bodies and Minds. Edinburgh: Edinburgh University Press.

Calkins, Mary Whiton. (1919) 'Review: A Defence of Idealism; Some Questions and Conclusions'. Harvard Theological Review, I2, I23-28.

Cunningham, G. Watts. (1933) The Idealistic Argument in Recent British and American Philosophy. New York: Century.

Dunham, Jeremy, Iain Grant, and Sean Watson. (20II) Idealism: The History of a Philosophy. London: Acumen.

Ford, Ford Madox. (I93 I) Return To Yesterday. London: Victor Gollancz.

Forster, Laurel. (2003) 'Nature's Double Vitality Experiment: May Sinclair's Interpretation of the New Woman'. In Ann Heilmann (ed.), Feminist Forerunners: New Womanism and Feminism in the Early Twentieth Century (London: Pandora), I68-69.

Gillespie, Diane. (1978) 'May Sinclair and the Stream of Consciousness: Metaphors and Metaphysics'. English Literature in Transition, I880-I920, 21, I34-42.

Glover, David. (200I) 'The "Spectrality Effect" in Early Modernism'. In Andrew Smith and Jeff Wallace (eds.), Gothic Modernisms (Basingstoke: Palgrave), 29-43.

Gough, Jim. (2009) 'May Sinclair, Idealism-Feminism and the Suffragist Movement'. Journal of the Canadian Society for the Study of Rhetoric, 3, I-I 7 .

Harvey, Andrew Edward. (I9I9) 'Review: A Defence of Idealism'. American Journal of Theology, 23, 554 .

Huggett, Nick. (2017) 'Zeno's Paradoxes'. In Edward N. Zalta (ed.), The Stanford Encyclopedia of Philosophy (Winter 2017 edition). https://plato.stanford.edu/archives/winzor $7 /$ entries/paradoxzeno/.

James, William. (I9ro) The Principles of Psychology. Vol. I. New York: Henry Holt.

Kersey, Ethel M. (1989) Women Philosophers. New York: Greenword Press.

Kunka, Andrew J., and Michele K. Troy, eds. (20I I) May Sinclair: Moving Towards the Modern. Aldershot: Ashgate.

Laird, John. (1923) 'Review: The New Idealism'. Mind, 32, I I6-I7.

Mander, W. J. (2000) 'Omniscience and Pantheism'. Heythrop Journal, 4I, I99-208.

Mander, W. J. (2005) 'Sinclair, May (or Mary Amelia St Clair: I863-I946)'. In Stuart Brown (ed.), Dictionary of Twentieth-Century British Philosophers (London: Continuum), 955-56.

Mander, W. J. (20I I) British Idealism: A History. Oxford: Oxford University Press.

Monk, Ray. (I996) Bertrand Russell. Vol. I. The Spirit of Solitude, I872-I92I. New York: Simon and Schuster.

Nagasawa, Yujin. (2008) God and Phenomenal Consciousness: A Novel Approach to Knowledge Arguments. Cambridge: Cambridge University Press.

Nagasawa, Yujin. (2013) 'The Maximal God and the Problem of Evil'. In Jeanine Diller and Asa Kasher (eds.), Models of God and Alternative Ultimate Realities (Dordrecht: Springer), 233-44.

Neff, Rebeccah Kinnamon. (1980) 'New Mysticism in the Writings of May Sinclair and T. S. Eliot'. Twentieth Century Literature, 26, 82-108.

Passmore, John. (1957) A Hundred Years of Philosophy. London: Gerald Duckwork. 
Pease, Alison. (2006) 'May Sinclair, Feminism and Boredom: “A Dying to Live”. English Literature in Transition, I880-1920, 49, I68-93.

Pringle-Pattison, Andrew Seth. (I 887) Hegelianism and Personality. Edinburgh: William Blackwood \& Sons.

Raitt, Suzanne. (2000) May Sinclair: A Modern Victorian. Oxford: Clarendon Press.

Russell, Bertrand. (I9r7a) 'Review: A Defence of Idealism; Some Questions and Conclusions'. Nation, 2I, 588-90.

Russell, Bertrand. (I9I7b) 'Review: A Defence of Idealism; Some Questions and Conclusions'. English Review, 25, 38I-84.

Russell, Bertrand. (I922) 'Review: The New Idealism'. Nation, 3I, 625-26.

Saunders, Max. (2007) 'Sinclair, Mary Amelia St Clair [May]'. Oxford Dictionary of National Biography. https://doi.org/I0.I093/odnb/9780I92683 I20.0I3.37966.

Sinclair, May. (I 886) Nakiketas and Other Poems. London: Kegan Paul.

Sinclair, May. (I9I7a) A Defence of Idealism; Some Questions and Conclusions. London: Macmillan.

Sinclair, May. (I9I7b) Letter to Bertrand Russell (I4 November I9I7). Bertrand Russell Archives MS 80782 056I07 5.46 RAi 7IO. McMaster University.

Sinclair, May. (1922) The New Idealism. London: Macmillan.

Sinclair, May. (1922-23) 'Primary and Secondary Consciousness'. Proceedings of the Aristotelian Society, 23, I I I-20.

Sinclair, May. (I926) Letter to Samuel Alexander (I6 March I926). Samuel Alexander Papers MSS ALEX/A/I/I/260/I-2. John Rylands University Library.

Sinclair, May. (2006) 'The Finding of the Absolute'. In Sinclair, Uncanny Stories (London: Wordsworth Editions), I6I-76.

Thomas, Emily. (2013) 'Space, Time, and Samuel Alexander'. British Journal for the History of Philosophy, 2I, 549-69.

Thomas, Emily. (2015) 'British Idealist Monadologies and the Reality of Time: Hilda Oakeley against McTaggart, Leibniz, and Others'. British Journal for the History of Philosophy, 23, I I $50-68$.

Thomas, Emily. (2017) 'The Roots of C. D. Broad's Growing Block Theory of Time'. Mind. https://doi.org/IO.I093/mind/fzxo2o.

Waithe, Mary Ellen. (I995) A History of Woman Philosophers. Vol. 4. Contemporary Women Philosophers, I90o-Today. Dordrecht: Kluwer Academic Publishers.

Warnock, Mary, ed. (I996) Women Philosophers. London: J. M. Dent. 